\title{
PENGARUH ENVIRONMENTAL PERFORMANCE PADA ECONOMIC PERFORMANCE DENGAN ENVIRONMENTAL DISCLOSURE SEBAGAI PEMEDIASI (Studi Empiris Pada Perusahaan Manufaktur Dan Pertambangan Yang Terdaftar Di Bursa Efek Indonesia)
}

\author{
Sylvia C. Daat, SE., M.Sc., Ak ${ }^{1}$ \\ sylviadaat@gmail.com \\ Bill J. C. Pangayow, SE., M.Si., Ak ${ }^{2}$ \\ Dosen Jurusan Akuntansi, Fakultas Ekonomi dan Bisnis Universitas Cenderawasih
}

\begin{abstract}
This research was motivated by the development of the direction of accounting research on green accounting issues. Companies that want a going concern operation must pay attention to $3 P$, namely profit as profit, people where companies must pay attention to the welfare of the community, and the planet is the company's contribution to the environment. Therefore, this study tries to find empirical evidence on the influence of several environmental variables, including the environmental performance of the company and disclosure of the company's environmental management activities to the public on the sustainability of the company with increasing economic (financial) performance of the company. The results of the study using the Structural Equation Model (SEM) approach with the Partial Least Square (PLS) method using Software WarpPLS 5.0 provide empirical evidence that the company's Environmental Performance influences the company's Economic Performance, but does not provide empirical evidence that environmental disclosure company as a conncecting variabel or mediating the relationship of environmental performance with economic performance
\end{abstract}

Keyword : environmental performance, economic performance, environmental disclosure.

\section{PENDAHULUAN}

Saat ini, operasi perusahaan tidak dapat hanya berfokus pada tujuan untuk maksimalisasi laba pemegang saham untuk mencapai kinerja ekonomi semata, tanpa memperhatikan dampak lingkungan dan sosial dari operasi tersebut. Elkingkton (1997) dalam Wiranata dkk (2014) mengemukakan bahwa jika suatu perusahaan ingin operasinya berkelanjutan (going concern) maka harus memperhatikan 3P yaitu profit sebagai keuntungan, people dimana perusahaan harus memperhatikan kesejahteraan masyarakat, dan planet merupakan kontribusi perusahaan terhadap lingkungan. Dengan demikian perusahaan dituntut untuk tidak hanya memperhatikan kepentingan penyedia dana saja (shareholders dan bondholders), tetapi juga memperhatikan kebutuhan pemangku kepentingan lainnya (stakeholders). Perusahaan diharapkan juga untuk memperhatikan kepentingan pihak-pihak seperti konsumen, pekerja, masyarakat, dan juga lingkungan dimana perusahaan tersebut beroperasi karena pihak-pihak tersebut dipengaruhi dan juga memengaruhi operasi perusahaan.

Beberapa kasus pencemaran lingkungan yang dilakukan oleh perusahaan-perusahaan industri beberapa tahun terakhir menyebabkan isu lingkungan menjadi sorotan masyarakat, investor dan juga pemerintah. Melihat kondisi lingkungan yang semakin memprihatinkan, dewasa ini tuntutan terhadap perusahaan semakin besar. Perusahaan diharapkan tidak hanya mengejar tercapainya kinerja finansial namun juga mencapai kinerja lingkungan serta memperhatikan masyarakat di sekitar perusahaan. Hal

\footnotetext{
${ }^{1}$ Dosen Jurusan Akuntansi FEB UNCEN
}

2 Dosen Jurusan Akuntansi FEB UNCEN 
ini menyebabkan banyak industri yang berusaha untuk menjadi industri yang ramah lingkungan karena para pemangku kepentingan (stakeholders) akan memberikan apresiasi kepada perusahaan yang memiliki kinerja lingkungan yang baik dan memberikan tekanan atau dorongan kepada perusahaan yang memiliki kinerja lingkungan yang kurang baik.

Kinerja lingkungan merupakan hubungan perusahaan dengan lingkungannya, berkaitan dengan dampak lingkungan dari sumber daya yang digunakan, efek lingkungan proses organisasi, implikasi lingkungan atas produk dan jasa, pemulihan pemrosesan produk, serta mematuhi peraturan lingkungan kerja. Teori Legitimasi kaitannya dengan kinerja lingkungan dan kinerja finansial perusahaan menunjukkan bahwa apabila terjadi ketidakselarasan antara sistem nilai perusahaan dan sistem nilai masyarakat (legitimacy gap), maka perusahaan dapat kehilangan legitimasinya yang selanjutnya akan mengancam kelangsungan hidup perusahaan (Almar dkk, 2012).Teori Legitimasi menyatakan bahwa suatu organisasi secara kontinu akan beroperasi sesuai dengan batas-batas dan nilai-nilai yang dapat diterima oleh masyarakat di sekitar perusahaan tersebut dalam usaha untuk mendapatkan legitimasi. Untuk mendapatkan legitimasi, perusahaan memiliki insentif untuk melakukan kegiatan sosial yang diharapkan oleh masyarakat.

Beberapa penelitian memberikan dukungan empiris bagaimana kinerja lingkungan perusahaan yang baik dapat meningkatkan kinerja keuangan perusahaan. Ortas et al (2013) menyatakan bahwa perusahaan yang aktif dan secara positif terlibat dalam isu-isu lingkungan dan sosial dapat menghasilkan resiko yang rendah dalam jangka waktu menengah hingga panjang. Penelitian yang dilakukan oleh Qi et al (2014) menemukan bahwa peningkatan environmental performance berpengaruh pada financial performance. Alvarez et al (2014) juga menemukan bahwa peningkatan kinerja lingkungan diikuti dengan peningkatan kinerja keuangan. Penelitian yang dilakukan oleh Singh dan Jackson (2015) menemukan bahwa perusahaan dengan peringkat lingkungan yang lebih tinggi, memiliki kinerja keuangan lebih tinggi dibandingkan perusahaan dengan peringkat kinerja lingkungan yang lebih rendah. Lee at al (2015) menemukan adanya pengaruh kinerja lingkungan terhadap kinerja perusahaan. Hasil penelitiannya menunjukkan adanya perilaku investor yang cenderung menghukum perusahaan yang berkinerja lingkungan rendah secara terus menerus, dilihat dari nilai Tobins Q dan ROA-nya.

Beberapa penelitian lain diantaranya oleh Iwata dan Okada (2014) tidak memberikan dukungan empiris pengaruh kinerja lingkungan terhadap kinerja keuangan. Sathye dan Rokhmawati (2015) menemukan pengaruh yang tidak signifikan dari kinerja lingkungan terhadap kinerja keuangan. Hortvathova (2010) tidak menemukan adanya hubungan kinerja lingkungan dengan kinerja keuangan. Sueyoshi dan Goto (2009) meneliti tentang investasi lingkungan dan pengaruhnya terhadap kinerja keuangan di Amerika Serikat. Hasil penelitiannya menemukan hubungan positif namun tidak signifikan dari investasi lingkungan terhadap kinerja keuangan.

Hasil-hasil penelitian yang beragam tentang pengaruh kinerja lingkungan terhadap kinerja keuangan perusahaan menimbulkan dugaan terdapatnya variabel yang memediasi hubungan kinerja lingkungan dengan kinerja ekonomi (keuangan). Hasil penelitian-penelitian tersebut menimbulkan dugaan bahwa pengaruh kinerja lingkungan terhadap kinerja ekonomi perusahaan tidak secara langsung, melainkan pengaruh tidak langsung, yaitu bahwa kinerja lingkungan memengaruhi kinerja ekonomi perusahaan melalui pengungkapan informasi pengungkapan aktivitas lingkungan (environmental disclosure) perusahaan.

Perusahaan dengan kinerja lingkungan yang baik cenderung mengungkapkan informasi aktivitas pengelolaan lingkungan dan tanggung jawab sosialnya dengan lebih lengkap kepada publik, dengan tujuan memperoleh legitimasi dari masyarakat. Seiring dengan hal tersebut, para investor akan tertarik untuk berinvestasi sehingga akan berdampak terhadap kinerja keuangan perusahaan. 
Penjelasan tersebut, didukung oleh hasil penelitian yang dilakukan oleh Rakhiemah dan Agustia (2009) yang menemukan bahwa kinerja lingkungan berpengaruh pada kinerja keuangan dengan pengungkapan CSR sebagai variabel intervening.

Berdasarkan teori-teori dan hasil-hasil penelitian sebelumnya, maka peneliti tertarik untuk melakukan penelitian dengan rumusan masalah, sebagai berikut:

1. Apakah kinerja lingkungan memengaruhi kinerja ekonomi?

2. Apakah kinerja lingkungan memengaruhi kinerja ekonomi melalui pengungkapan lingkungan (environmental disclosure)?

Dengan demikian penelitian ini mempunyai tujuan sebagai berikut:

1. Memperoleh bukti empiris pengaruh kinerja lingkungan terhadap kinerja ekonomi perusahaan.

2. Memperoleh bukti empiris pengaruh tidak langsung kinerja lingkungan terhadap kinerja ekonomi yang dimediasi oleh pengungkapan lingkungan (environmental disclosure).

\section{TINJAUAN PUSTAKA}

Berbagai perspektif teori telah digunakan untuk menjelaskan praktek pengungkapan tanggung jawab sosial dan lingkungan perusahaan.

\subsection{Teori Legitimasi}

Legitimasi suatu organisasi dapat dilihat sebagai sesuatu yang diberikan masyarakat kepada perusahaan dan sesuatu yang diinginkan atau dicari perusahaan dari masyarakat. Teori Legitimasi menegaskan bahwa perusahaan terus berupaya memastikan bahwa mereka beroperasi dalam bingkai dan norma yang ada dalam masyarakat atau lingkungan dimana perusahaan berada. Perusahaan berusaha memastikan bahwa aktivitas mereka diterima oleh masyarakat sebagai sesuatu yang sah (Deegan, 2002).

Yang melandasi teori legitimasi adalah kontrak sosial yang terjadi antara perusahaan dengan masyarakat dimana perusahaan beroperasi dan menggunakan sumber ekonomi. Dowling dan Pfeffer (1975) dalam Ghozali dan Chariri (2007) mengatakan bahwa legitimasi tidak hanya dapat didefinisikan dengan mengatakan apa yang legal atau ilegal. Harapan masyarakat terhadap perusahaan dapat bersifat implisit atau eksplisit. Bentuk eksplisit dari kontrak sosial adalah pernyataan legal, sementara bentuk implisitnya adalah harapan masyarakat yang tidak tercantum dalam peraturan legal (uncodified community expectation) (Deegan, 2000 dalam Ghozali dan Chairiri (2007)).

Jadi pada dasarnya semua perusahaan memiliki kontrak implisit dengan masyarakat untuk melakukan kegiatannya berdasarkan nilai-nilai yang dijunjung di dalam masyarakat. Jika suatu perusahaan memenuhi sebuah kontrak implisit dengan stakeholder, stakeholder akan bertindak sebagaimana yang diinginkan perusahaan. Sebaliknya ketika kontrak implisit dengan stakeholder tidak dipenuhi maka terjadi kemungkinan kontrak yang implisit akan berubah menjadi suatu hal yang eksplisit dan akan menimbulkan biaya yang lebih tingi. Perbedaan antara nilai-nilai perusahaan dengan nilai-nilai masyarakat disebut Legitimacy Gap dan dapat memengaruhi perusahaan untuk melanjutkan usahanya. Perusahaan yang selalu berusaha untuk menyelaraskan diri dengan normanorma yang ada di masyarakat dan mengantisipasi terjadinya legitimacy gap maka perusahaan tersebut dapat terus dianggap sah dalam masyarkat dan dapat terus bertahan hidup (Rokhmi, 2007).

Anggraini (2006) menyatakan bahwa dalam usaha memperoleh legitimasi, perusahaan melakukan kegiatan sosial dan lingkungan. Perusahaan memerhatikan keadaan sosial dan lingkungan di sekitarnya karena dengan kepedulian tersebut, keberadaan perusahaan dapat diterima masyarakat, sehingga keberlangsungan hidup perusahaan dapat terus bertahan. 


\subsection{Teori Stakeholder}

Stakeholder merupakan sekelompok individu, sekelompok manusia, komunitas atau masyarakat baik secara keseluruhan ataupun secara parsial yang memiliki hubungan serta kepentingan terhadap perusahaan. Teori stakeholder menyatakan bahwa semua stakeholder mempunyai hak memperoleh informasi mengenai aktivitas perusahaan yang dapat memengaruhi pengambilan keputusan mereka. Hal ini disebabkan stakeholder dianggap dapat memengaruhi tetapi juga dapat dipengaruhi oleh perusahaan. Dengan demikian, keberadaan suatu perusahaan sangat dipengaruhi oleh dukungan yang diberikan oleh stakeholder kepada perusahaan tersebut.

Alasan yang mendorong perusahaan perlu memerhatikan keberadaan stakeholder yaitu: (1) isu lingkungan melibatkan kepentingan berbagai kelompok dalam masyarakat yang dapat mengganggu kualitas hidup mereka, (2) dalam era globalisasi, produk-produk yang diperdagangkan didorong untuk harus bersahabat dengan lingkungan, (3) para investor dalam menanamkan modalnya cenderung untuk memilih perusahaan yang memiliki dan mengembangkan kebijakan dan program lingkungan, (4) LSM dan pecinta lingkungan makin vokal dalam mengkritik perusahaan-perusahaan yang kurang peduli terhadap lingkungan.

\subsection{Kinerja Lingkungan}

Kinerja lingkungan (environtmental performance) perusahaan adalah kinerja perusahaan dalam menciptakan lingkungan yang baik (green) (Suratno, Darsono, Mutmainah, 2006). Di Indonesia kinerja lingkungan perusahaan dinilai dan dievaluasi melalui program yang dibuat oleh Kementerian Lingkungan Hidup yang disebut PROPER (Program Penilaian Peringkat Kinerja Perusahaan dalam Pengelolaan Lingkungan Hidup). Penilaian kinerja lingkungan dalam penelitian ini diukur dengan penilaian peringkat PROPER. Tujuan dari penilaian tersebut adalah untuk meningkatkan kinerja perusahaan dalam pelestarian di bidang lingkungan. Dalam laporan tahunannya, Kementerian Lingkungan Hidup menjelaskan bahwa penilaian kinerja ketaatan perusahaan dalam PROPER dilakukan berdasarkan atas kinerja perusahaan dalam memenuhi berbagai persyaratan yang ditetapkan dalam peraturan perundang-undangan yang berlaku dan kinerja perusahaan dalam pelaksanaan berbagai kegiatan yang terkait dengan kegiatan pengelolaan lingkungan yang belum menjadi persyaratan penaatan (beyond compliance).

Kinerja ketaatan yang dinilai dalam PROPER mencakup ketataan terhadap pengendalian pencemaran air, udara, pengelolaan limbah B3, dan penerapan AMDAL (Analisis Mengenai Dampak Lingkungan). Sedangkan penilaian untuk aspek upaya lebih dari taat meliputi penerapan sistem manajemen lingkungan, pemanfaatan limbah dan konservasi sumber daya, dan pelaksanaan kegiatan pengembangan masyarakat (community development). Berikut ini adalah indikator peringkat kinerja yang digunakan dalam menilai peringkat kinerja perusahaan. Perusahaan akan diberi penilaian warna emas apabila perusahaan tersebut telah melakukan pengelolaan lingkungan lebih dari yang dipersyaratkan dan telah melakukan upaya 3R (Reduce, Reuse, Recycle), menerapkan sistem pengelolaan lingkungan yang berkesinambungan, serta melakukan upaya-upaya yang berguna bagi kepentingan masyarakat pada jangka panjang.

Perusahaan akan diberikan warna hijau apabila telah melakukan upaya pengelolaan lingkungan lebih dari yang dipersyaratkan, telah mempunyai sistem pengelolaan lingkungan, mempunyai hubungan yang baik dengan masyarakat, termasuk melakukan 3R (Reduce, Reuse, Recycle). Perusahaan akan diberikan warna biru apabila telah melakukan upaya pengelolaan lingkungan yang dipersyaratkan sesuai dengan peraturan atau ketentuan yang berlaku. Sedangkan warna biru minus diberikan apabila perusahaan melakukan upaya pengelolaan lingkungan, tetapi baru sebagian 
mencapai hasil yang sesuai dengan persyaratan sebagaimana diatur dalam peraturan perundangundangan.

Perusahaan akan diberikan penilaian warna merah apabila melakukan upaya pengelolaan lingkungan, tetapi baru sebagian kecil mencapai hasil yang sesuai dengan persyaratan sebagaimana diatur dalam peraturan perundang-undangan. Perusahaan diberikan penilaian warna hitam apabila belum melakukan upaya pengelolaan lingkungan, berarti secara sengaja tidak melakukan upaya pengelolaan lingkungan sebagaimana yang dipersyaratkan serta berpotensi mencemari lingkungan.

\subsection{Environmental Disclosure}

Environtmental disclosure merupakan kumpulan informasi yang berhubungan dengan aktivitas pengelolaan lingkungan oleh perusahaan di masa lalu, sekarang, dan akan datang (Al-Tuwajiri, 2004). Informasi ini dapat diperoleh dengan banyak cara seperti pernyataan kualitatif, asersi atau fakta kuantitatif, bentuk laporan keuangan atau catatan kaki. Bidang environtmental disclosure meliputi hal-hal sebagai berikut: pengeluaran atau biaya operasi untuk fasilitas dari peralatan pengontrol polusi di masa lalu dan sekarang. Dalam mengukur environtmental disclosure terdapat suatu check list yang berisi item-item pengungkapan yang nantinya akan dicocokkan dengan pengungkapan yang terdapat dalam laporan tahunan perusahaan. Item-item tersebut mewakili 12 pengungkapan dalam laporan tahunan (Chrismawati, 2007).

\subsection{Economic Performance}

Kinerja lingkungan berhubungan dengan faktor-faktor non keuangan serta faktor-faktor keuangan seperti kinerja keuangan, harga saham, dan biaya modal. Economic performance adalah kinerja perusahaan-perusahaan secara relatif dalam suatu industri yang sama yang ditandai dengan return tahunan industri yang bersangkutan. Economic performance suatu perusahaan pada dasarnya diperlukan sebagai alat untuk mengukur kesehatan keuangan suatu perusahaan (financial health).

Perusahaan sebagai salah satu bentuk organisasi, pada umumnya memiliki tujuan tertentu yang ingin dicapai dalam usaha untuk memenuhi kepentingan para anggotanya. Keberhasilan dalam mencapai tujuan perusahaan merupakan prestasi manajemen. Penilaian prestasi atau kinerja suatu perusahaan diukur karena dapat dipakai sebagai dasar pengambilan keputusan baik pihak internal maupun pihak eksternal. Penilaian kinerja keuangan merupakan salah satu cara yang dapat dilakukan oleh pihak manajemen agar dapat memenuhi kewajibannya terhadap para penyandang dana dan juga untuk mencapai tujuan yang telah ditetapkan oleh perusahaan (Ermayanti).

Sucipto (2003) mendefinisikan kinerja keuangan sebagai penentuan ukuran-ukuran tertentu yang dapat mengukur keberhasilan suatu perusahaan dalam menghasilkan laba. Berry dan Rondonelli dalam Ja'far dan Arifah (2006) menjelaskan bahwa kepedulian terhadap lingkungan juga merupakan salah satu faktor yang memengaruhi kinerja keuangan. Kepedulian terhadap lingkungan muncul akibat berbagai dorongan dari pihak luar antara lain pemerintah, konsumen, investor, dan stakeholder lainnya. Untuk menindaklanjuti berbagai dorongan ini maka perlu diciptakan pendekatan secara proaktif dalam meminimalkan dampak lingkungan yang terjadi. Pengungkapan kinerja lingkungan yang baik, menjadikan keberadaan perusahaan dalam menjalankan aktivitas perusahaan diterima oleh masyarakat sehingga dapat mewujudkan kinerja keuangan yang baik.

\subsection{Penelitian Terdahulu dan Pengembangan Hipotesis}

\subsubsection{Pengaruh Environmental Performance terhadap Economic Performance}

Beberapa penelitian menemukan bahwa kinerja lingkungan memengaruhi kinerja ekonomi (finansial) perusahaan. Dengan memiliki kinerja lingkungan yang baik, citra perusahaan meningkat 
di masyarakat, sehingga selanjutnya akan berdampak pada peningkatan kinerja ekonomi (keuangan) perusahaan. Menurut Januarti dan Apriyanti (2005) masyarakat dan konsumen yang simpati terhadap kepedulian sosial perusahaan akan merespon aktivitas sosial perusahaan ini dengan mengkonsumsi produk yang dihasilkan perusahaan sehingga hal ini akan berimplikasi pada kinerja keuangan perusahaan melalui terciptanya penjualan.

Darnall (2005) menemukan bahwa perusahaan dengan tingkat pertumbuhan yang tinggi, kinerja lingkungan berpengaruh positif pada kinerja keuangan sedangkan pada perusahaan dengan tingkat pertumbuhan yang rendah, kinerja lingkungan berpengaruh negatif pada kinerja keuangan.. Penelitian Suratno et al. (2006) menemukan bahwa kinerja lingkungan berpengaruh terhadap kinerja keuangan perusahaan. Almilia dan Wijayanto (2007) menemukan adanya pengaruh kinerja lingkungan terhadap kinerja keuangan.

Berdasarkan teori dan hasil penelitian tersebut, maka hipotesis penelitian ini adalah:

H1: Environmental performance berpengaruh pada economic performance

\subsubsection{Pengaruh Environmental Performance pada Economic Performance melalui Environmental Disclosure}

Pengungkapan atas aktivitas atau kinerja perusahaan yang semakin baik akan menjadi sebuah good news bagi pelaku pasar modal. Pengungkapan informasi mengenai aktivitas atau kinerja perusahaan merupakan hal penting bagi stakeholder terutama investor. Perusahaan yang memiliki kinerja yang baik merupakan good news yang direspon positif oleh investor. Verrecchia (1983) dalam Suratno at al (2006) menyatakan bahwa pelaku lingkungan yang baik percaya bahwa mengungkapkan kinerja mereka menggambarkan good news bagi pelaku pasar. Oleh karena itu, perusahaan dengan kinerja lingkungan yang baik perlu mengungkapkan informasi kuantitas dan mutu aktivitas kepedulian lingkungannya yang lebih dibandingkan dengan perusahaan yang memiliki kinerja lingkungan yang buruk.

Perusahaan yang memiliki good news seperti kinerja lingkungan yang baik akan meningkatkan pengungkapan kinerjanya tersebut dalam laporan tahunan dengan harapan good news tersebut akan direspon positif oleh investor, karena hal tersebut mencerminkan transparansi perusahaan bahwa perusahaan juga bertanggung jawab terhadap apa yang telah dilakukannya (Fitriyani, 2012) sehingga selanjutnya berdampak positif pada peningkatan kinerja keuangan perusahaan. Dengan demikian, kinerja lingkungan yang baik, akan mendorong perusahaan mengungkapkan good news tersebut melalui pengungkapan lingkungan (environmental disclosure) dalam laporan tahunan perusahan, dan pengungkapan lingkungan tersebut akan berpengaruh pada peningkatan kinerja keuangan perusahaan.

Penelitian terkait pengaruh environmental disclosure sebagai variabel intervening yang memediasi hubungan kinerja lingkungan dengan kinerja keuangan belum banyak dilakukan. Hasil penelitian Angela dan Yudianti (2015) menemukan bahwa CSR bukan variabel intervening pengaruh kinerja lingkungan pada kinerja keuangan. Sedangkan penelitian Rachmawati dan Ahmad (2012) dan Pujiasih (2013) menunjukkan CSR sebagai variabel mediasi pengaruh peringkat PROPER pada ROA (Return on Asset). Penelitian Damanik dan Yadhyana (2017) menemukan bukti empiris pengaruh kinerja lingkungan pada kinerja keuangan perusahaan melalui pengungkapan tanggung jawab sosial perusahaan sebagai variabel pemediasi.

Berdasarkan teori dan hasil penelitian sebelumnya, maka rumusan hipotesis penelitian ini adalah: 


\section{H2: Environmental performance berpengaruh pada economic performance melalui environmental disclosure}

\subsection{Peta Jalan (Road Map) Penelitian}

\section{Gambar 1}

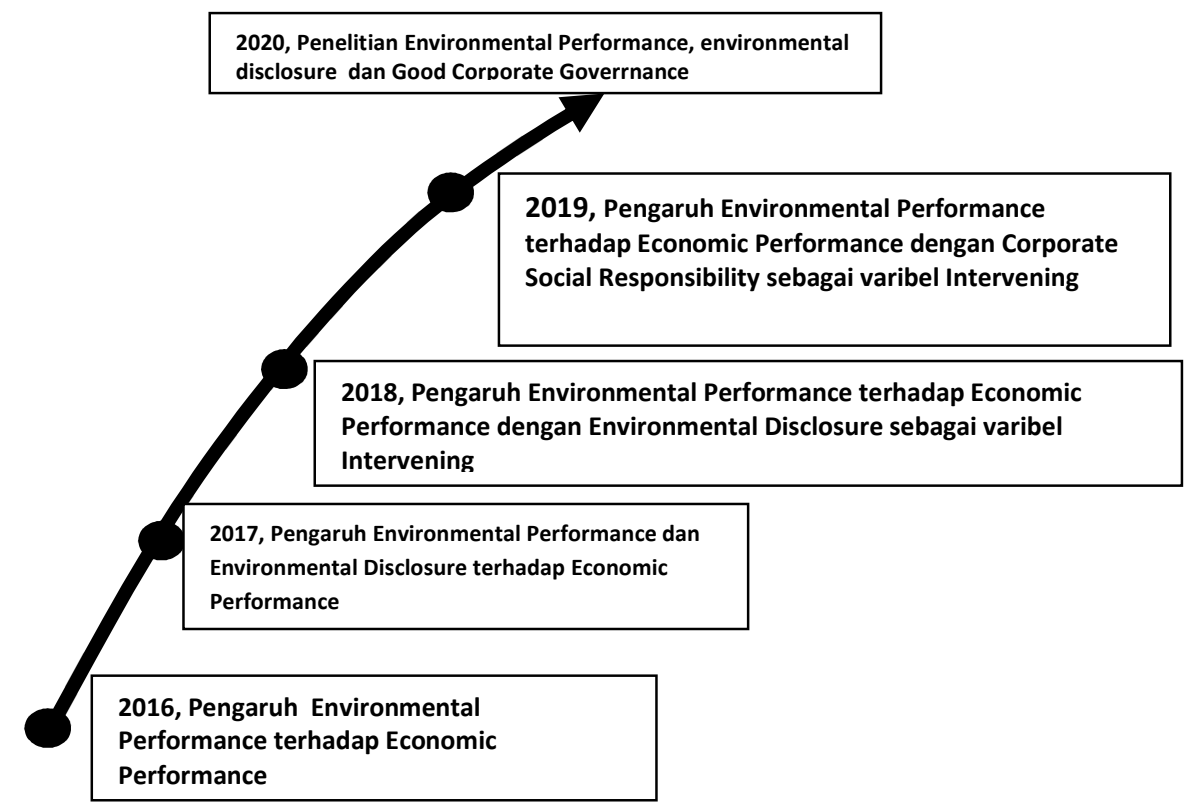

Sumber: Penulis (2018)

\section{METODE PENELITIAN}

\subsection{Jenis Penelitian}

Jenis penelitian ini dirancang sebagai penelitian kausal dengan pendekatan kuantitatif. Penelitian kausal berguna untuk mengukur hubungan antara variabel riset, atau untuk menganalisis pengaruh suatu variabel terhadap variabel lainnya. Peneliti menggunakan desain penelitian ini untuk memberikan bukti empiris dan menganalisis pengaruh variabel environmental performance terhadap economic performance perusahaan dengan environmental disclosure sebagai variabel pemediasi.

\subsection{Populasi dan Sampel Penelitian}

Populasi yang digunakan dalam penelitian ini adalah perusahaan manufaktur, pertambangan umum dan industri migas, yang terdaftar di Bursa Efek Indonesia (BEI). Penelitian ini mengambil sampel perusahaan yang go publik yang mengikuti program penilaian PROPER pada tahun 20112015 dengan mengambil sampel secara purposive (purposive sampling) yaitu sampel ditarik sejumlah tertentu dari populasi dengan menggunakan pertimbangan tertentu. Dalam hal ini sampel yang diambil harus memenuhi beberapa karakteristik berikut:

1. Perusahaan yang bergerak di bidang manufaktur, pertambangan umum, dan industri migas yang go publik dan terdaftar di Bursa Efek Indonesia dan menerbitkan laporan keuangan per tanggal 31 Desember 2011-2015.

2. Perusahaan yang melaporkan laporan keuangannya dalam mata uang rupiah. 


\subsection{Jenis dan Sumber Data}

Jenis data yang digunakan dalam penelitian ini adalah data kuantitatif, yaitu merupakan data yang berbentuk bilangan atau angka. Penelitian ini menggunakan data sekunder berupa laporan tahunan perusahaan manufaktur, pertambangan umum, dan industri migas yang diperoleh dari Indonesian Stock Exchange serta laporan penilaian PROPER yang dipublikasikan oleh Kementerian Lingkungan Hidup melalui website Kementerian Lingkungan Hidup.

\subsection{Variabel Penelitian dan Definisi Operasional Variabel}

\subsubsection{Variabel Penelitian}

Variabel dependen yang digunakan dalam penelitian ini adalah Economic Performance (Y), variabel independen (X) dalam penelitian ini adalah Environmental Performance, dan variabel pemediasi adalah environmental disclosure.

\subsubsection{Definisi Operasional}

\subsubsection{Variabel Economic Performance}

Varibel dependen yang digunakan dalam penelitian ini adalah variabel economic performance. Economic performance adalah kinerja perusahaan-perusahaan secara relatif dalam suatu industri yang sama yang ditandai dengan return tahunan industri yang bersangkutan. Dalam penelitian ukuran kinerja ekonomi yang digunakan adalah kinerja saham perusahaan yang diukur menggunakan return saham (capital market-based measure):

$\mathbf{E c P}=(\mathbf{P 1}-\mathbf{P 0}) / \mathbf{P 0}$

Keterangan : $\mathrm{Ecp}=$ Economic Performance

$\mathrm{P} 1$ = harga saham akhir tahun (adjusted dividen stock split)

$\mathrm{P} 0=$ harga saham awal tahun

\subsubsection{Variabel Environmental Performance}

Kinerja lingkungan (environtmental performance) perusahaan adalah kinerja perusahaan dalam menciptakan lingkungan yang baik (green) (Suratno, Darsono, Mutmainah, 2006). Penilaian kinerja lingkungan dalam penelitian ini diukur dengan penilaian peringkat PROPER. Sistem peringkat kinerja PROPER mencakup pemeringkatan perusahaan dalam 5 (lima) warna yang akan diberi skor berturut-turut dengan nilai tertinggi 5 untuk warna emas dan terendah 1 untuk warna hitam.

\subsubsection{Variabel Environmental Disclosure}

Environmental disclosure adalah pengungkapan informasi yang berkaitan dengan lingkungan di dalam laporan tahunan perusahaan. Environmental disclosure perusahaan diukur dengan disclose-scoring yang diperoleh dari analisis laporan keuangan dengan menggunakan suatu checklist yang berisi 74 item pengungkapan yang digunakan oleh Chrismawati (2007). Sebuah item diberi nilai 1 bila diungkapkan dalam laporan tahunan, dan diberi nilai 0 apabila tidak diungkapkan dalam laporan tahunan.

\subsection{Metode Analisis Data}

Analisis data dalam penelitian ini menggunakan pendekatan Structural Equation Model (SEM) dengan metode Partial Least Square (PLS) dengan menggunakan solfware WarpPLS 5.0. PLS adalah model persamaan struktural (SEM) yang berbasis komponen atau varian (variance). Menurut Ghozali (2011) PLS merupakan pendekatan alternatif yang bergeser dari pendekatan SEM 
berbasis covariance menjadi berbasis varian.SEM yang berbasis kovarian umumnya menguji kausalitas/teori sedangkan PLS lebih bersifat predictive model. Langkah-langkah analisis PLS sebagai berikut:

1) Merancang Model Struktural (inner model)

Perancangan model struktural hubungan antara variabel laten pada PLS didasarkan pada rumusan masalah atau hipotesis penelitian.

2) Merancang Model Pengukuran (outer model)

Perancangan model pengukuran dalam PLS sangat penting karena terkait dengan apakah indikator bersifat reflektif atau formatif. Model reflektif secara matematis menempatkan indikator sebagai sub-variabel yang dipengaruhi oleh variabel laten, sehingga indikatorindikator tersebut bisa

dikatakan dipengaruhi oleh faktor yang sama yaitu variabel latennya. Model yang digunakan dalam penelitian ini adalah model reflektif dengan asumsi semua indikator seolah-olah dipengaruhi variabel laten.

3) Mengkonstruksi diagram Jalur

4) Konversi diagram Jalur ke dalam Sistem Persamaan

a. Evaluasi Outer Model

Wiyono (2011:398) menyatakan evaluasi outer model digunakan untuk menspesifikasi hubungan antara variabel laten dengan indikatornya.

b. Evaluasi Inner Model

Wiyono (2011:399) menyatakan evaluasi inner model digunakan untuk menspesifikasi hubungan antar variabel laten yang satu dengan variabel laten yang lainnya dengan tingkat signifikansi $5 \%$.

5) Estimasi

Nilai estimasi koefisien jalur antara konstruk harus memiliki nilai yang signifikan. Signifikansi hubungan dapat diperoleh dengan prosedur Bootstapping. Nilai yang dihasilkan berupa nilai t-hitung yang kemudian dibandingkan dengan t-tabel. Apabila nilai t-hitung $>$ ttabel $(1,95)$ pada taraf signifikansi 0,05 maka nilai estimasi koefisien jalur tersebut signifikan.

6) Goodness of fit

Pada tahap ini dilakukan pengujian terhadap kesesuaian model melalui berbagai kriteria goodness of fit. Goodness of fit dalam PLS dibagi atas dua bagian yaitu sebagai berikut.

a. Outer Model

Wiyono (2011:403) menyatakan kriteria penilaian yang digunakan dalam menilai indikator adalah :

1. Convergent validity nilai loading factor 0,50 sampai 0,60 .

2. Discriminant validity nilai korelasi cross loading dengan variabel latennya harus lebih besar dibandingkan dengan korelasi terhadap variabel laten yang lain.

3. Nilai AVE harus diatas 0,50.

4. Nilai composite reliability yang baik apabila memiliki nilai $\geq 0,70$.

b. Inner Model

Goodness of fit pada inner model diukur menggunakan R square variabel laten dependen, Q square predictive relevance untuk model struktural yang digunakan untuk mengukur seberapa baik nilai observasi dihasilkan oleh model dan juga estimasi parameternya. Nilai Q square > 0 menunjukkan model memiliki predictive relevance yang baik, sebaliknya jika nilai Q square $\leq 0$ menunjukkan model kurang memiliki predictive relevance. 
Penelitian ini akan menguji pengaruh langsung dan pengaruh tidak langsung variabel environmental performance terhadap economic performance. Metoda Analisis Jalur (Path Analysis) digunakan untuk menguji pengaruh varibel intervening. Persamaan regresi yang digunakan adalah sebagai berikut:

$$
\begin{aligned}
& \mathrm{EcP}=\alpha+\beta 1 \operatorname{EnP}+e \\
& \mathrm{EnD}=\alpha+\beta 1 E n P+e \\
& \mathrm{EcP}=\alpha+\beta 1 E n D+e
\end{aligned}
$$

Keterangan:
$\alpha \quad$ : Konstanta
$\beta$ : Koefisien Regresi
EcP : Economic Performance
EnP : Environmental Performance
EnD: Environmental Disclosure
$e \quad:$ Error

\section{HASIL PENELITIAN DAN PEMBAHASAN \\ 4.1 Deskriptif Objek Penelitian}

Penelitian ini dilakukan dengan tujuan untuk menganalisis pengaruh environmental performance terhadap economic performance melalui variabel environmental disclosure sebagai pemediasi, perusahaan-perusahaan manufaktur dan pertambangan yang terdaftar di Bursa Efek Indonesia, selama periode tahun 2011 hingga tahun 2015. Selama tahun 2011 sampai dengan tahun 2015, tercatat 127 perusahaan manufaktur yang terdaftar di BEI. Menggunakan metoda purposive sampling untuk menyeleksi sampel telah dilakukan dan diperoleh 29 perusahaan manufaktur yang memenuhi syarat sebagai sampel penelitian. Berikut adalah tabel seleksi sampel penelitian.

Tabel 1

\section{Pemilihan Sampel Penelitian}

\begin{tabular}{|c|l|c|}
\hline NO & \multicolumn{1}{|c|}{ KETERANGAN } & $\begin{array}{c}\text { JUMLAH } \\
\text { PERUSAHAAN }\end{array}$ \\
\hline 1 & $\begin{array}{l}\text { Perusahaan Manufaktur dan Pertambangan yang terdaftar } \\
\text { di BEI tahun 2011 sampai 2015. }\end{array}$ & 187 \\
\hline 2 & $\begin{array}{l}\text { Perusahaan yang tidak menyajikan laporan keuangan } \\
\text { secara berturut-turut selama tahun penelitian dan } \\
\text { menggunakan mata uang Asing. }\end{array}$ & (85) \\
\hline 3 & $\begin{array}{l}\text { Perusahaan yang tidak mengikuti Program PROPER } \\
\text { Kementerian Lingkungan Hidup }\end{array}$ \\
\hline \multicolumn{2}{|c|}{ Jumlah Sampel yang Terpilih } & 30 \\
\hline \multicolumn{2}{|c|}{ Jadi, Total Observasi yang diteliti dari tahun 2011-2015 berjumlah “30x5=150” } \\
\hline
\end{tabular}

Sumber: Data Olah Penulis (2018)

Tahap pertama dalam proses pemilihan sampel penelitian adalah perusahaan Manufaktur dan Pertambangan yang terdaftar di Bursa Efek Indonesia (BEI) selama periode waktu tahun 2011 sampai tahun 2015 tercatat 187 perusahaan manufaktur dan pertambangan yang mempublikasikan laporan keuangannya di Bursa Efek Indonesia. Informasi Jumlah Perusahaan Diperoleh dari website www.sahamok.co.id. 
Tahap kedua, sampel yang dipilih dalam penelitian adalah perusahaan manufaktur yang mempublikasikan informasi laporan keuangan dalam mata uang Rupiah dan terdaftar secara berturutturut selama 5 (lima) tahun pengamatan, yaitu dari tahun 2011 sampai 2015. Dari 187 perusahaan terdapat total 85 perusahaan yang tidak terdaftar secara berturut-turut di BEI selama tahun pengamatan dan menyajikan laporan keuangan dalam mata uang Dolar AS.

Tahap ketiga dalam seleksi sampel penelitian terfokus pada data yang dibutuhkan dalam penelitian ini, yaitu keikutsertaan perusahaan sampel pada Program penilaian peringkat kinerja perusahaan dalam Lingkungan Hidup (PROPER). Pada tahap ini, terdapat 72 perusahaan yang dieliminasi karena tidak tidak mengikuti Program PROPER Kementerian Lingkungan Hidup.

Berdasarkan 3 (tiga) tahap seleksi sampel tersebut, terdapat 30 perusahaan yang dapat dijadikan sampel penelitian selama 5 tahun pengamatan, atau terdapat total 150 observasi.

\subsection{Statistik Deskriptif}

Analisis statistik diskriptif bertujan untuk menggambarkan atau menjelaskan sebaran data yang diteliti agar mudah dipahami karakteristik dari data penelitian tersebut. Analisis statistik diskriptif meliputi minimum, maximum, mean, dan standar deviasi. Minumum menunjukan nilai terendah dari data, maximum menunjukan nilai tertinggi dari data, mean menunjukan rata-rata dari data, dan standar devisiasi menunjukan sebaran data dari setiap variabel yang diteliti.

Didasarkan pada metoda purposive sampling, untuk memperoleh sampel penelitian maka didapat 150 observasi yang bisa dijadikan sampel penelitian. Metoda purposive sampling yaitu metoda seleksi sampel penelitian dengan menentukan kriteria-kriteria untuk memperoleh sampel dengan karakteristik yang sesuai dengan penelitian yang akan dibuat.

Selengkapnya mengenai statistic deskriptif data penelitian dapat dilihat pada tabel berikut:

\section{Tabel 2}

Statistik Deskriptif

Descriptive Statistics

\begin{tabular}{|l|r|r|r|r|r|}
\hline & $\mathrm{N}$ & Minimum & Maximum & Mean & Std. Deviation \\
\hline EcP & 150 & 3,892 & 11,212 & 7,38172 & 2,027785 \\
EnP & 150 & 1 & 5 & 3,12 & 0,75 \\
EnD & 150 & 0,135 & 0,959 & 0,46973 & 0,197733 \\
Valid N & 150 & & & & \\
(listwise) & & & & & \\
\hline
\end{tabular}

Sumber: Data Olah Penulis (2018)

Berdasarkan tabel di atas terdapat 3 (tiga) variabel dalam penelitian ini dengan penjelasan mengenai hasil perhitungan statistic deskriptif sebagai berikut:

\subsubsection{Environmental Performance}

Dari data pada tabel statistik deskriptif diatas, rata-rata kinerja lingkungan perusahaan manufaktur dan pertambangan di Indonesia perioda tahun 2011-2015 adalah sebesar 3,12 dengan standar deviasi 0.75 . Nilai kinerja lingkungan terendah adalah 1 dan nilai tertinggi adalah 5 . 
Berdasarkan data tersebut, rata-rata kinerja lingkungan pada perusahaan manufaktur dan pertambangan yang menjadi sampel adalah baik.

\subsubsection{Environmental Disclosure}

Dari data pada tabel statistik deskriptif diatas, rata-rata pengungkapan lingkungan perusahaan manufaktur dan pertambangan di Indonesia perioda tahun 2011-2015 adalah sebesar 46,97\% dari total item pengungkapan dengan standar deviasi 19,77\%. Jumlah pengungkapan lingkungan terendah adalah 13,5\% dan jumlah pengungkapan lingkungan tertinggi adalah 95,9\% . Berdasarkan data tersebut, rata-rata pegnungkapan lingkungan pada perusahaan manufaktur dan pertambangan yang menjadi sampel masih cukup rendah, yaitu masih kurang dari 50\% dari item pengungkapan yang ada.

\subsubsection{Economic Performance}

Kinerja ekonomi (keuangan) dalam penelitian ini diukur dengan menggunakan perhitungan return saham pada tahun pengamatan. Dari data tabel statistik deskriptif, rata-rata kinerja ekonomi sampel sebesar 7,38 dengan standar deviasi sebesar 2,028. Nilai kinerja ekomomi terendah adalah sebesar 3,892 dan kinerja ekonomi tertinggi adalah sebesar 11,212.

\subsection{Analisis Data}

\subsubsection{Uji Koefisien Determinasi $\left(R^{2}\right)$}

Uji Koefisien Determinasi bertujuan untuk mengetahui seberapa besar kemampuan model menjelaskan variasi di dalam variabel dependen (Ghozali, 2011). Nilai $\mathrm{R}^{2}$ berkisar antara 0 sampai 1 $\left(0 \leq \mathrm{R}^{2} \leq 1\right)$, semakin nilai $\mathrm{R}^{2}$ mendekati angka 1 , semakin besar pengaruh variabel independen terhadap variabel dependen yang berarti variabel-variabel independen yang dipakai dalam penelitian memberikan hampir semua informasi yang dibutuhkan untuk memprediksi variasi variabel dependen. Sebaliknya jika nilai $\mathrm{R}^{2}$ semakin mendekati angka 0 , maka semakin kecil pengaruh variabel independen terhadap variabel dependent yang berarti variabel-variabel independen yang dipakai dalam penelitian hanya memberikan sedikit informasi yang dibutuhkan untuk memprediksi variasi variabel dependen dan sebagian besar diberikan oleh variabel independen lainnya. Berikut adalah hasil pengujian koefisien determinasi $\left(\mathrm{R}^{2}\right)$ dengan pengolahan data menggunakan PLS:

\section{Tabel 3}

\section{Adjusted R-Square}

\begin{tabular}{|c|c|}
\hline Variabel & R-Square \\
\hline EnPerf $\longrightarrow$ EnvDisc & 0,13 \\
\hline EnDisc $\longrightarrow$ EcPerf & 0,17 \\
\hline
\end{tabular}

Sumber: Data Olah Penulis (2018)

Hasil analisis yang disajikan pada tabel diatas menunjukkan besarnya $\quad$ R-Square pengaruh variabel kinerja lingkungan terhadap pengungkapan lingkungan adalah sebesar 0,13. Nilai R-Square 0,13 dapat diartikan bahwa sebesar $13 \%$ varian dari variabel pengungkapan lingkungan dapat dijelaskan oleh variabel kinerja lingkungan, sementara sekitar 87\% sisanya dijelaskan oleh variabel lain di luar model. Sementara itu besarnya R-Square pengaruh variabel pengungkapan lingkungan terhadap kinerja ekonomi adalah sebesar 0,17. Nilai R-Square 0,17 dapat diartikan bahwa sebesar 
$17 \%$ varian dari variabel kinerja ekonomi dapat dijelaskan oleh variabel pengungkapan lingkungan, sementara sekitar $83 \%$ sisanya dijelaskan oleh variabel lain di luar model.

\section{Q-Square}

Suatu model dianggap mempunyai nilai predictive yang relevan jika nilai Q-Square lebih besar dari $0(>0)$. Hasil perhitungan Q-Square pada penelitian ini adalah 0,132 dan 0,173 . Hal ini berarti model dalam penelitian ini layak untuk menjelaskan variabel endogen yaitu pengungkapan lingkungan dan kinerja ekonomi.

\subsubsection{Pengujian Hipotesis}

Hubungan antar konstuk laten dalam model penelitian dapat dilihat dari hasil estimasi koefisien jalur (path coefficient) dan tingkat signifikansinya ( $p$-value).

Untuk menguji hipotesis penelitian yang diajukan, dapat dilihat dari:

1. Jika $t$ hitung $>\mathrm{t}$ tabel, atau tingkat signifikansi $<\alpha=0,05$ maka hipotesis didukung.

2. Jika $\mathrm{t}$ hitung $<\mathrm{t}$ tabel atau tingkat signifikansi $>\alpha=0,05$ maka hipotesis tidak didukung.

Hasil estimasi path coefficients untuk menguji kekuatan pengaruh antar variabel dan menjelaskan ketegasan hubungan antar arah variabel dapat dilihat pada tabel sebagai berikut.

\section{Tabel 4}

Hasil estimasi path coefficients

\begin{tabular}{|l|c|c|c|}
\hline \multicolumn{1}{|c|}{ Hipotesis } & $\begin{array}{c}\text { Path } \\
\text { Coefficients }\end{array}$ & P-Value & Keterangan \\
\hline $\begin{array}{l}\text { Kinerja Lingkungan } \\
\text { (EnvPerf) > Kinerja } \\
\text { Ekonomi (EcPerf) }\end{array}$ & 0,327 & $<0,001$ & Signifikan \\
\hline $\begin{array}{l}\text { Kinerja Lingkungan } \\
\text { (EnvPerf) } \\
\begin{array}{l}\text { Pengungkapan } \\
\text { Lingkungan } \\
\text { (ErvDisc) } \\
\text { inerja Ekonomi } \\
\text { (EcPerf) }\end{array}\end{array}$ & 0,059 & 0,168 & $\begin{array}{c}\text { Tidak } \\
\text { Signifikan }\end{array}$ \\
\hline
\end{tabular}

Sumber: Hasil output WarpPLS 5.0 (2018)

\subsection{Pembahasan}

\subsubsection{Environmental Performance berpengaruh terhadap Economic Performance (hipotesis 1)}

Hasil penelitian menunjukkan bahwa hipotesis 1 didukung dengan koefisien sebesar 0,327 dengan tingkat signifikansi sebesar $<0.001$ yaitu lebih kecil dari 0,05. Bukti empiris penelitian ini sejalan dengan bebrapa penelitian, diantaranya penelitian yang dilakukan oleh Qi et al (2014) menemukan bahwa peningkatan environmental performance berpengaruh pada financial performance. Alvarez et al (2014) juga menemukan bahwa peningkatan kinerja lingkungan diikuti dengan peningkatan kinerja keuangan. Penelitian yang dilakukan oleh Singh dan Jackson (2015) menemukan bahwa perusahaan dengan peringkat lingkungan yang lebih tinggi, memiliki kinerja keuangan lebih tinggi dibandingkan perusahaan dengan peringkat kinerja lingkungan yang lebih rendah. Lee at al (2015) menemukan adanya pengaruh kinerja lingkungan terhadap kinerja perusahaan. 


\subsubsection{Environmental Performance berpengaruh terhadap Economic Performance melalui Environmental Disclosure sebagai Pemediasi (hipotesis 2)}

Hasil penelitian menunjukkan bahwa hipotesis 2 tidak didukung dengan koefisien sebesar 0,059 dan dengan tingkat signifikansi 0,168. Artinya bahwa tingkat pengungkapan lingkungan perusahaan tidak memediasi hubungan antara kinerja lingkungan perusahaan dengan kinerja ekonomi perusahaan. Bukti empiris penelitian ini tidak menemukan pengaruh pengungkapan lingkungan sebagai pemediasi pada hubungan antara kinerja lingkungan dan kinerja ekonomi seperti penelitian oleh Angela dan Yudianti (2015) yang menemukan bahwa CSR bukan variabel intervening pengaruh kinerja lingkungan pada kinerja keuangan.

\section{PENUTUP}

\subsection{Kesimpulan}

Berdasarkan hasil analisis data dan pembahasan yang telah dilakukan, maka dapat diambil kesimpulan sebagai berikut:

1. Kinerja Lingkungan perusahaan mempengaruhi Kinerja Ekonomi Perusahaan.

2. Tingkat pengungkapan lingkungan perusahaan tidak memediasi hubungan antara kinerja lingkungan perusahaan dengan kinerja ekonomi perusahaan.

\subsection{Saran}

Saran untuk penelitian selanjutnya yang didasarkan pada keterbatasan yang dialami peneliti akan diuraikan sebagai berikut:

1. Nilai Adjusted R Square masih tergolong kecil oleh karena itu penelitian selanjutnya dapat mencoba menambahkan variabel independen yang diduga berpengaruh pada kinerja ekonomi perusahaan. 


\section{DAFTAR PUSTAKA}

Almar, M., Rima Rahmawati, dan Asfia Murni. 2012. Pengaruh Pengungkapan Corporate Social Responsibility terhadap Profitabilitas Perusahaan. Seminar Nasional Akuntansi dan Bisnis Universitas Widyatama Bandung.

Almilia dan Wijayanto. 2007.Pengaruh Environmental Performance dan Environmental Disclosure pada Economic Performance. Proeedings The $1^{\text {st }}$ Accounting Conference

Al-Tuwajiri. 2004. The Relations Among Environmental Disclosure, Environmental Performance, and Economic Performance: A Simultaneous Equations Approach. Accounting, Organizations, dan Society Vol.29 Hal. 447-471

Bondan, I. Darsono, \& Mutmainah. 2006. Hubungan Antara Kinerja Lingkungan dengan Kinerja Ekonomi dan Pengungkapan Lingkungan. Simposium Nasional Akuntansi IX Padang, 22.

Chrismawati, D.T.. 2007. Pengaruh Karakteristik Keuangan dan Non Keuangan Perusahaan terhadap Praktik Environmental Disclosure di Indonesia. Seminar Perpustakaan Ekonomi Referensi http://jurnal unipa.ac.id./index

Damanik, I Gst. Agung Bagus Adi, \& I Ketut Yadnyana. 2017. Pengaruh Kinerja Lingkungan pada Kinerja Keuangan dengan Pengungkapan Corporate Social Responsibility sebagai Variabel Intervening. E-Jurnal Akuntansi Universitas Udayana Vol. 20.1 (Juli).

Handayani, A.R. 2010. Pengaruh Environmental Performance terhadap Environmental Disclosure dan Economic Performance serta Environmental Disclosure terhadap Economic Performance. Skripsi. Universitas Diponegoro Semarang.

Suratno, Darsono, \& Mutmainah. 2006. Pengaruh Environmental Performance terhadap Environmental Disclosure dan Economic Performance. Simposium Nasional Akuntansi IX. Padang 